\title{
Determinants of bank credit growth in Nigeria 1980-2010
}

By

\author{
Akinlo $^{1}$, A. Enisan PhD and $\mathrm{Oni}^{2}$, I. Oluwafemi $\mathrm{MPh}$
}

\begin{abstract}
The paper analyses the dominant factors influencing bank credit to private sector in Nigeria over the period 1980-2010 using the error correction modeling technique. The results show that broad money, cyclical risk premium and liquidity ratio tend to increase credit to the private sector. However, prime lending rate and reserve ratio lead to a reduction in credit to the private sector. Private credit increases with inflation, but not one to one, meaning that inflation tends to dampen real bank credit to the private sector.
\end{abstract}

Key Words: credit growth, banking sector, industry, error correction model.

\section{Introduction}

In the literature, three main idea about the importance of the credit in economic development are summarized as: one, that countries with better functioning banks and markets grow faster, but the degree to which a system is bank-based or market-based is not important; two, that these conclusions do not seem to be influenced by simultaneity bias; and three, better functioning financial system ease the external financial constraint that impede firm expansion (Levine, 2005). This, indeed, informs the consensus of opinion that credit to the private sector is an important mechanism through which financial development matters for growth. Based on this, determinant of banks credit have recently been a subject of a growing body of empirical work. However, the issue still remains largely unresolved.

Asides, most existing studies on the determinants of credit growth are focused on developed and industrialized countries with many institutional structures that are different from developing countries. This, by implications, means that some of the results obtained for the developed and industrialized countries might not hold for developing countries such as Nigeria. There is, therefore, the need for more studies on the determinants of credit growth in developing countries such as Nigeria. This is particularly compelling in the light of the boom-burst cycles many developing economies experienced before and after the global crisis. 
Essentially, this work is motivated by the following factors. These factors are: one, lack of consensus amongst existing studies on those factors that determine credit; two, scarcity of empirical work on determinants of credit in developing economies such as Nigeria and three, the need to verify the relevance of some of the established determinants of credit growth in developed economies to developing economies. Essentially, the findings will provide insights into how the situations in Nigeria compare with that of developed and industrialized economies.

The rest of the paper is organized as follows: section 2 provides the review of literature; section 3 discusses the methodology and model specification, section 4 presents and discusses the results while section 5 concludes.

\section{Literature review}

In this section, we provide summary of recent studies on determinants of credit to the private sector. The study by Takats (2010) found that supply shock was the main determinant of slowdown in cross-credit border lending to emerging markets during the crises. Barajas, et al (2010) found that banks level fundamentals- capitalization and loan quality explained the differences in credit growth across Middle Eastern and North African Countries.

The study by Aisen and Franken (2010), prior to financial crisis the bank credit growth was larger as compared to post crisis period. The authors showed that countercyclical monetary policy and liquidity position of the banks played a crucial role and lessened the bank credit reduction in the post crisis era. Guo and Stepanyan (2011) showed that domestic and foreign funding had positive association with credit growth. The paper found that stronger economic growth would lead to higher credit growth, while higher inflation would reduce real credit growth. Expansionary or loose monetary conditions either domestic or global, would lead to increase credit. The same applies to strong banking sector. This means that healthy banking sector will lead to increase credit growth.

Moreno et al. (2012) study for Colombia found that interbank rate, national-debt-toGDP, household-consumption-to-GDP and the level of investment-to-GDP were the main determinants of credit portfolio-GDP. The result showed that financial deepening variable was positive and significant. Sharma and Gounder (2012) study for six Pacific Island countries (Fiji, Papua New Guinea, Solomon Islands, Vanuta, Samao and Tonga) found that rising average lending and inflation rate could be detrimental to credit growth, while deposit and asset size would contribute positively to credit growth. The results equally showed that stronger economic growth would lead to higher credit growth.

The study by Imran (2011) for Pakistan showed that foreign liabilities, domestic deposits, economic growth, exchange rate and monetary conditions had significant impact on credit particularly in the long run. However, inflation and money market rate had no effect on private credit. Asides, the results showed that the financial wealth and liquidity as well as economic condition measured as GDP of the bank were significant determinants of credit. 


\section{Methodology}

This paper uses a time series approach to the development of econometric credit growth model to analyse the factors that influence credit to the private sector. Engle and Granger (1987) suggest a two-step approach. First, the existence of a cointegrating relationship among the variables under consideration is determined based on standard cointegration techniques. In a situation where the variables are stationary, a stable longrun relationship can be estimated using standard ordinary least squares (OLS) techniques. Second, the information in the error term of the long-run relationship is used to create a dynamic error correction model. As pointed out by Engle and Granger (1987), the error correction model produces consistent results even when the right-hand side variables are not completely exogenous.

Model Specification

The benchmark specification of our regression that broadly follows the literature on the subject is as follows:

$$
\begin{aligned}
& P S C_{t}=\beta_{0}+\beta_{1} M 2_{t}+\beta_{2} L Q D_{t}+\beta_{3} B S Z_{t}+\beta_{4} I N F_{t}+\beta_{5} R E S_{t}+\beta_{6} C R P_{t}+\beta_{7} P L R_{t}+\beta_{8} E X R_{t} \\
& +\beta_{9} M R_{t}+\beta_{10} R G D P_{t}+\mu_{t} \ldots \ldots \ldots \ldots \ldots \ldots \ldots \ldots \ldots \ldots \ldots \ldots . .(1)
\end{aligned}
$$

where: credit to the private sector (PSC) is the dependent variable while the explanatory variables are broad money supply (M2), liquidity ratio (LQD), bank total asset (a proxy for bank size/capitalization) (BSZ), Inflation rate (INF), reserve ratio (RES), cyclical risk premium (CRP) prime lending rate (PLR), exchange rate (EXR), minimum rediscount ratio (MRR), real gross domestic product (RGDP), $(\mu)$ is the disturbance term and $\mathrm{t}$ is the time subscript. We used annual data spanning the period 1980-20101.

\section{Empirical Results}

Conventionally, we first explore the stationarity properties of the analysed time series data using ADF- and Phillip Perron tests. For space consideration, the empirical results are not presented but they show that all the variables are all integrated of order 1 or I(1). Consequently, we conducted cointegration analysis using Engle and Granger (1987) approach. A cointegrating relationship was confirmed for the PSC, RGPD, M2, LQD, BSZ, INF, PLR, and EXR variables. The ADF and Phillip Peron test statistics rejected the hypothesis of the existence of a unit root in the error term of the regression of the variables, with PSC as the dependent variable, confirming that the error term was stationary.

Estimation of the long-run relationship yielded (with t-statistic in parentheses): $P S C=1.353+0.364 B S Z+0.537 M 2-0.037 R G D P+0.238 C R P-0.081 E X R$
(0.724) (1.864)*
$(2.152)^{* *}$
$(-0.159)$
$(3.026)^{* * *}(-1.003)$

\footnotetext{
${ }^{1}$ The sources of data and description of the variables are given in Appendix A.
} 


$$
\begin{array}{cccc}
+0.182 I N F+0.189 L Q D-0.233 M R R & -0.193 R E S-0.241 P L R & \ldots \ldots \ldots \ldots \\
(1.724)^{*}(0.644) & (-0.568) & (-4.202)^{* * *} & (-1.651)^{*}
\end{array}
$$

Sample: $1980-2010$ Adj $\mathrm{R}^{2}=0.998$ SE $=0.107 \mathrm{~F}=1249 \mathrm{DW}=1.8$

Note: $* * *, * *$ and $*$ denote significance at $1 \%, 5 \%$ and $10 \%$ respectively.

The model performed reasonably well in terms of explaining credit growth as a function of the included variables. The adjusted $\mathrm{R}^{2}$ is very high and the F-statistic is significant. The results show that in the long run, bank total assets, money supply broadly defined, cyclical risk premium and inflation have significant positive effect on credit growth while reserve ratio and prime lending rate have significant negative effect on credit growth ${ }^{2}$.

Dynamic Model

The dynamic version of the long-run relationship estimated in equation 2 can be specified as an error correction model:

$$
\begin{aligned}
& \Delta P S C_{t}=\beta_{0}+\sum_{i=0}^{n}\left(\beta_{1 i} \Delta M 2_{t_{-i}}+\beta_{2 i} \Delta L Q D_{t_{-i}}+\beta_{3 i} \Delta B S L_{t_{-i}}+\beta_{4 i} \Delta I N T_{t_{-i}}+\right. \\
& \left.\beta_{5 i} \Delta R E S_{t_{-i}}+\beta_{6 i} \Delta C R P_{t_{-i}}+\beta_{7 i} \Delta P L R_{t_{-i} i}+\beta_{8 i} \Delta E X R_{t_{-i}}+\beta_{9 i} \Delta M R R_{t_{-i}}+\beta_{10 i} \Delta R G D P_{t_{-i}}\right)+ \\
& \beta_{11} E C_{t-i}+V_{t}
\end{aligned}
$$

where $\Delta$ represents the first difference operator, EC the error correction term, and $\mathrm{v}_{\mathrm{t}}$ a disturbance term. All other variables are as defined earlier.

The error correction model utilizes information in the error term of the long-run model to approximate deviations from the equilibrium and represents the short run response necessary to move the system back toward its equilibrium. The error term is calculated as:

$E C_{t}=P S C_{t}-P S C_{t}$

where $\mathrm{PSC}_{\mathrm{t}}$ is the actual value of PSC in period t and PSC $\mathrm{t}_{-}$is the fitted value of $\mathrm{PSC}_{t}$ estimated in equation (2).

Equation 4 was used to estimate the short run model given below (with the t-statistic in parentheses)

$$
\begin{aligned}
& \Delta \mathrm{PSC}=-0.025+0.196 \Delta B S Z+0.858 \Delta M 2-0.407 \Delta R G D P+0.140 \Delta C R P-0.074 \Delta E X R \\
& (-0.536)(1.318)^{*} \quad(4.666)^{* * *}(-1.927) \quad * \quad(2.577)^{* *}(-1.358)^{*}
\end{aligned}
$$

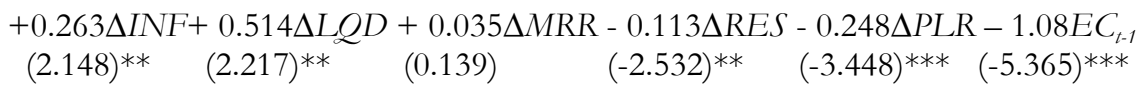

Sample: $1980-2010$ Adj $\mathrm{R}^{2}=0.792 \mathrm{SE}=0.074 \mathrm{~F}=10.69 \mathrm{DW}=1.50$

Note: $* * *, * *$ and $*$ denote significance at $1 \%, 5 \%$ and $10 \%$ respectively.

The model was estimated using OLS estimation techniques on annual data for the period 1982-2010. It conformed well in terms of the expected signs on the coefficients of the explanatory variables and in terms of its explanatory power, with an adjusted

\footnotetext{
${ }^{2}$ However, the coefficients of bank assets, inflation and prime lending rate are only significant at 10 per cent level
} 
coefficient of determination $\left(\mathrm{R}^{2}\right)$ value of 0.792 . When the error correction model was fitted against historical credit data, it performed well in terms of tracking the cyclical nature of credit growth in Nigeria. The presence of serial correlation, or more general form of autocorrelation, was rejected based on the Breusch-Godfrey and Box-Pierce Q statistic. The Jacque-Bera test statistic confirmed normality, and the ARCH test rejected up to fourth-order heteroscedasticity in the disturbance term. The presence of a general specification error was rejected based on the results of the Ramsey RESET (1) test. The estimated error correction model was found to be stable over the period studies based on the Recursive residuals, One-step Probability Recursive residuals and CUSUM recursive residuals test as shown in Fig.1 (a-c) below.

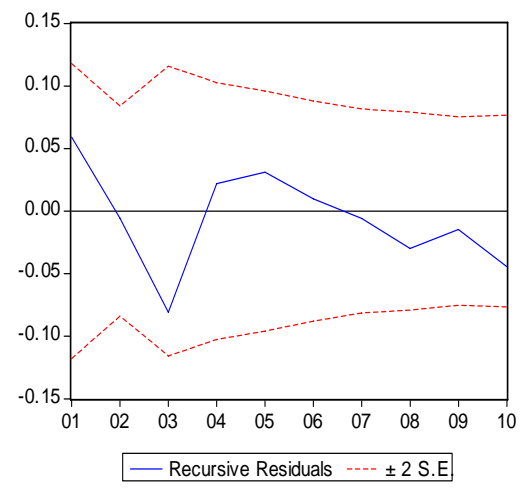

(a)

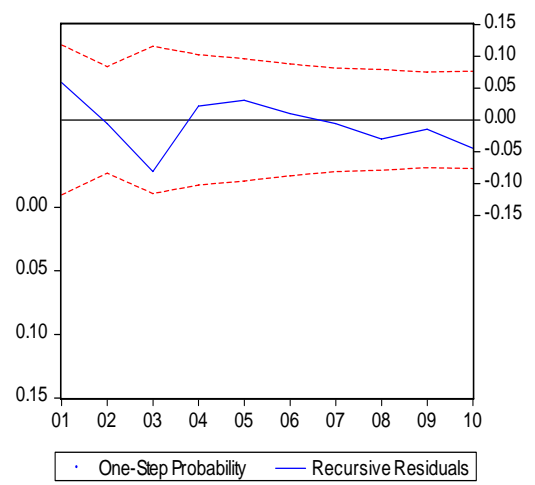

(b)

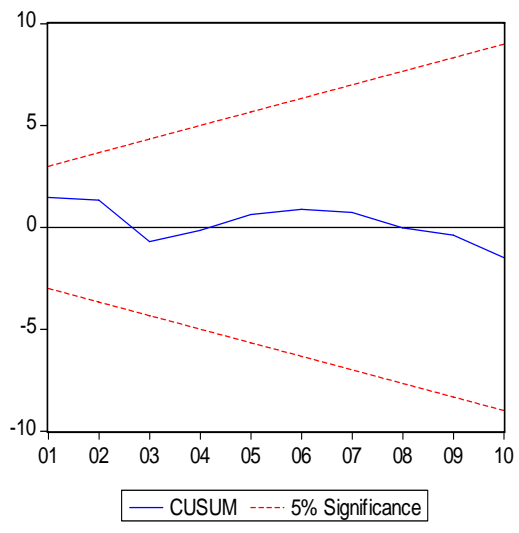

(c)

Fig 1(a-c): Plots of recursive residuals, one-Step probability Recursive and CUSUM respectively.

The results show that money supply broadly defined is positive and significant at 1 per cent. A 1 per cent increase in money supply will lead to 0.18 percent increase in credit to the private sector. This should not come as a surprise because increase money supply 
tends to enhance commercial banks ability to create deposits and their ability to extend credit to the private investors.

The results show that growth rate gross domestic product has adverse effect on credit growth in the short run though only significant 10 per cent level. 1 per cent increase in GDP leads to 0.4 per cent reduction in credit growth. This result is contrary to a priori expectation. This is inconsistent with the findings of Sharma and Gounder (2012) for six Pacific Island countries and Imran (2011) for Pakistan. The possible reason for this contrary result could be the composition of the GDP. Oil constitutes a major component of the GDP. The value added in the sector is extremely low and with very minimal linkage with the other sub-sectors. In this wise, the GDP growth might not necessarily translate into higher credit growth in the economy. Moreover, over the years the growth rate of the GDP has been low and unstable. And since GDP growth measures the overall health of the economy; it is no surprise therefore that GDP has significant negative effect on credit growth.

The results show that private credit increases with inflation, but less than one to one, which implies that inflation in fact, dampens real private credit growth. This result is consistent with the findings of Guo and Stepanyan (2011) for some selected emerging economies and Imran (2011) for Pakistan. However, the result contradicts the findings of Sharma and Gounder (2012) for six Pacific Island countries.

Liquidity ratio has a significant positive effect on credit growth. This is contrary to the expected negative sign. This is based on the fact that a high liquidity tends to curtail credit creation capability of the banks. However, in view of the fact that banks in Nigeria tends to have excess reserves as a result of huge resources from oil, monetary policy such as liquidity ratio and the likes, may not have adverse effect on credit growth in the country.

The results show that prime lending rate and reserve ratio have significant negative effect on credit growth. The results show that 1 per cent increase in prime lending rate and reserve ratio will reduce credit growth by 0.25 and 0.11 per cent respectively. The result for lending rate conforms to earlier finding by Sharma and Gounder (2012) for some selected Pacific Island countries. Finally, cyclical risk premium measured as the difference between lending and saving rate has significant positive effect on credit growth. The result tends to support the argument that the higher the difference between deposit and lending rates, the higher the returns to the banks and the greater the incentive to give credit ${ }^{3}$.

The relative fit and efficiency of EC regression is averagely alright and as the theory predicts, the EC term is negative and significant. The coefficient value and sign of $E C_{t-}$ 1(approximately 1.0) indicates that any disequilibrium formed in the short run will be temporary and get fully corrected 100 per cent over a period of a year.

\footnotetext{
${ }^{3}$ However, there is the counter argument that high difference between lending and deposit rates tends to discourage potential savers and thus limiting the quantum of funds available to potential investors.
} 


\section{Conclusion}

Our estimation results show that private credit increases with money supply, cyclical risk premium, and liquidity ratio. However, reserve ratio and prime lending rate tend to reduce private credit. Therefore, based on the findings, we discuss certain policy implications. Given that prime lending rate is likely to be detrimental to bank credit to private sector, policies designed to keep this rate in check would appear to be useful. Secondly, policies that foster ease monetary conditions in the economy would be beneficial to private sector credit growth. Such policies will entail low reserve ratio and expansionary money supply.

Third, low inflation is conducive to real credit growth. Therefore, policies that improve fundamentals and lower inflation are not only beneficial on their own right; they could also boost credit growth. Fourth, policies geared toward increasing the bank size and keep the bank healthy matter for credit growth. A banking sector with strong asset base is desirable not only for financial stability, but also credit growth.

\section{Appendix A}

A.1. Sources of data

Source (a) Central Bank of Nigeria, (CBN), Statistical Bulletin 2011 edition

Source (b) World Bank, World Development Indicators, 2011 edition.

A.2. Description and Measurement of variables

PSC Credit to the private sector

M2 Broad money defined as the sum of narrow money plus quasi money.

LQD Liquidity ratio as prescribed by the monetary authority

BSZ Bank total assets

INF Inflation rate

RES Reserve ratio

CRP Cyclical risk premium. This is measured as the difference between lending and deposit rates.

PLR Prime lending rate

EXR Exchange rate

MRR Minimum rediscount rate

RGDP Real gross domestic product. This is nominal domestic product deflated by consumer price index.

\section{References}

Aisen, A. and Franken, M. (2010). Bank credit during the 2008 financial crisis: a cross-country comparison. IMF Working Paper $10 / 47$.

Barajas, A.,Chami, R., Espinoza, R., and Hesse, H. (2010). Recent credit stagnation in the MENA region: what to expect? What can be done? IMF Working Paper 10/219.

Engle, R. F., and Granger, C. W. J. (1987). Co-integration and error correction: representation, estimation and testing. Econometrica, 55:251-76. 
Guo K. and Stepanyan V. (2011). Determinants of bank credit in emerging market economies. IMF Working Paper no 51: 1-20.

Imran K. (2011). Determinants of bank credit in Pakistan. Proceedings of $2^{\text {nd }}$ International Conference on Business Management, Institute of Business Administration, Karachi, Pakistan. Pp. 1-32.

Levine, R. (2005). Finance and Growth: theory and evidence. In P. Aghion and S. Durlauf (Eds.) Handbook of economic growth, (pp 865-943). Elsevier.

Moreno, A., Moreno, D. and Estrada, D. (2012). Credit determinants and their impact on firm's growth in Colombia. Banco de la Republica Working Paper no 67: 1-24.

Sharma, P. and Gounder, N. (2012). Determinants of bank credit in small open economic: The case of six Pacific Island countries. Griffith Business School Discussion Paper no. 13, pp. 1-18.

Takats E. (2010). Was it credit supply? Cross-border bank lending to emerging market economies during the financial crisis. BIS Quarterly Review, June: 49-56. 